\title{
Management of severe ARDS due to SARS-CoV-2 pneumonia using low-flow extracorporeal $\mathrm{CO}_{2}$ extraction
}

\author{
Rosario Molina Lobo ${ }^{1,2}$, Beatriz Lobo-Valbuena ${ }^{1,2}$ and Federico Gordo $2,3^{*}$
}

Keywords: ARDS, Coronavirus infection, Respiratory failure, Extracorporeal circulation, Patient outcome assessment

Extracorporeal $\mathrm{CO}_{2}$ extraction $\left(\mathrm{ECCO}_{2} \mathrm{R}\right)$ is a technique that uses an extracorporeal device to extract excess $\mathrm{CO}_{2}$ from the blood by passing it through an air exchange membrane using low blood flows and requiring systemic anticoagulation for its use. The main technical difference with extracorporeal membrane oxygenation system (ECMO) is the reduced blood flow (between 300 and $500 \mathrm{ml} / \mathrm{min}$ ), achieving the elimination of most of the $\mathrm{CO}_{2}$ produced by metabolism, thanks to the greater solubility of this gas in plasma.

This technique emerged from the need to decouple the oxygenation support from the ventilation support provided by ECMO with the main objective of optimising lung protection during mechanical ventilation (MV) [1]. There is currently no strong evidence regarding the benefit provided by the use of $\mathrm{ECCO}_{2} \mathrm{R}$ in this clinical context [2].

We present a series of 8 cases of patients with severe global respiratory failure due to COVID-19, admitted in ICU between December 2020 and May 2021. Regarding patients' characteristics, we highlight mean values of ICU stay of 45.8 days ( \pm standard deviation 15.8 ), PaFi of 75.1 $( \pm 10.4)$ and $\mathrm{pH} 7.25( \pm 0.03)$, despite endotracheal intubation (ETI) and protective MV with Pplat $29.1( \pm 1.61)$. Prone position was necessary in all cases, both before and after $\mathrm{ECCO}_{2} \mathrm{R}$ placement. The mean number of days in

\footnotetext{
*Correspondence: fgordo5@gmail.com

${ }^{2}$ Grupo de Investigación en Patología Crítica, Facultad de Ciencias de La Salud, Universidad Francisco de Vitoria, Pozuelo de Alarcón, Madrid, Spain Full list of author information is available at the end of the article
}

prone position prior to $\mathrm{ECCO}_{2} \mathrm{R}$ was 3.75 days $( \pm 1.08)$. Mean number of days from the start of ETI to the start of $\mathrm{ECCO}_{2} \mathrm{R}$ was 14.5 days, $\mathrm{PaO} 2 / \mathrm{FiO} 2$ of 75.1 and SOFA score 6.6. Transfer to ECMO was not possible in any of the 8 cases, following to the current recommendations of the receiving centres [3].

All cases had positive SARS-CoV-2 polymerase-chainreaction detection and severe respiratory failure without severe dysfunction of other organs or documented infections.

During ICU admission, selected patients presented persistent hypoxaemia and hypercapnia refractory to lung protective measures (TV 6-8 $\mathrm{ml} / \mathrm{kg}$, Pplat $<30$ ) and proning. $\mathrm{ECCO}_{2} \mathrm{R}$ support was considered then, preserving the level of lung protection and correcting the expected deterioration of ventilation with worsening respiratory acidosis obtained after achieving an increase in PEEP. Our objectives were also to decrease Pplat in a range of less than 28 , to decrease respiratory rate under $25 \mathrm{bpm}$ and to decrease TV (under $7 \mathrm{ml} / \mathrm{kg}$ ).

Table 1 shows the respiratory status prior to initiation of therapy, and Table 2 shows the results obtained $12-24 \mathrm{~h}$ after initiation of the $\mathrm{ECCO}_{2} \mathrm{R}$.

The therapeutic objectives of ProLUNG ${ }^{\circledR}$ (blood flow $400 \mathrm{ml} / \mathrm{min}$ and air flow $15 \mathrm{~L} / \mathrm{min}$ ), with a rise in $\mathrm{pH}$ (7.32-7.35), were achieved in the first $12 \mathrm{~h}$ of treatment. Results are shown in Table 2. Regarding technical complications, thrombocytopenia not induced by heparin was observed in one of the cases, requiring withdrawal of treatment after 5 days. original author(s) and the source, provide a link to the Creative Commons licence, and indicate if changes were made. The images or other third party material in this article are included in the article's Creative Commons licence, unless indicated otherwise in a credit line to the material. If material is not included in the article's Creative Commons licence and your intended use is not permitted by statutory regulation or exceeds the permitted use, you will need to obtain permission directly from the copyright holder. To view a copy of this licence, visit http://creativecommons.org/licenses/by/4.0/. The Creative Commons Public Domain Dedication waiver (http://creativecommons.org/publicdomain/zero/1.0/) applies to the data made available in this article, unless otherwise stated in a credit line to the data. 
Table 1 Characteristics

\begin{tabular}{|c|c|c|c|c|c|c|c|c|c|c|}
\hline $\mathbf{N}$ & $\operatorname{Sex}(F / M)$ & Age (yr) & BMI $\left(\mathrm{kg} / \mathrm{m}^{2}\right)$ & $\begin{array}{l}\text { Days Symp/ } \\
\mathrm{ECCO}_{2} \mathrm{R}\end{array}$ & $\begin{array}{l}\text { Days EIT/ } \\
\text { ECCO }_{2} R\end{array}$ & $\begin{array}{l}\text { Compliance } \\
\left(\mathrm{ml} / \mathrm{cmH}_{2} \mathrm{O}\right)\end{array}$ & $\mathrm{PO}_{2} / \mathrm{FiO}_{2}$ & $\begin{array}{l}\text { Days on } \\
\mathrm{ECCO}_{2} \mathrm{R}\end{array}$ & $\begin{array}{l}\text { ICU LOS after } \\
\mathrm{ECCO}_{2} \mathrm{R}\end{array}$ & Out \\
\hline 1 & $\mathrm{~F}$ & 53 & 33 & 26 & 15 & 17 & 64 & 5 & 47 & a \\
\hline 2 & $\mathrm{~F}$ & 55 & 37 & 25 & 11 & 13 & 70 & 7 & 33 & a \\
\hline 3 & M & 74 & 28 & 53 & 13 & 34 & 96 & 1 & 24 & $d$ \\
\hline 4 & M & 67 & 33 & 29 & 19 & 8 & 71 & 6 & 23 & $d$ \\
\hline 5 & $F$ & 61 & 32 & 16 & 21 & 28 & 61 & 4 & 12 & a \\
\hline 6 & M & 69 & 36 & 20 & 9 & 42 & 78 & 3 & 20 & $d$ \\
\hline 7 & M & 69 & 36 & 23 & 14 & 35 & 81 & 5 & 8 & a \\
\hline 8 & M & 64 & 25 & 23 & 14 & 14 & 80 & 8 & 1 & $d$ \\
\hline
\end{tabular}

$\mathrm{N}=$ Number of cases, $\mathrm{F}=$ female, $\mathrm{M}=$ male, $\mathrm{Yr}=$ years, $\mathrm{BMI}=$ body mass index, Days Symp/ECCO ${ }_{2} \mathrm{R}=$ number of days from symptom onset to $\mathrm{ECCO}{ }_{2} \mathrm{R}$ placement, Days $E I T / E C C_{2} R=$ number of days from intubation to $E C C_{2} R$ placement, $L O S=$ length of stay after $E C C_{2} R$, Out. = outcome, $a=$ alive, $d=$ death

Table 2 Data before and after 24-h initiating $\mathrm{ECCO}_{2} \mathrm{R}$

\begin{tabular}{|c|c|c|c|c|c|c|c|c|c|c|c|c|}
\hline \multirow[b]{2}{*}{$N$} & \multicolumn{6}{|c|}{ Before $\mathrm{ECCO}_{2} \mathrm{R}$} & \multicolumn{6}{|c|}{ After $\mathrm{ECCO}_{2} \mathrm{R}$ and PEEP trial } \\
\hline & $\mathrm{TV}(\mathrm{ml} / \mathrm{kg})$ & Pplat $\left(\mathrm{cmH}_{2} \mathrm{O}\right)$ & $\mathrm{DP}\left(\mathrm{cmH}_{2} \mathrm{O}\right)$ & $\operatorname{PEEP}\left(\mathrm{cmH}_{2} \mathrm{O}\right)$ & $\mathrm{pCO}_{2}$ & $\mathrm{FiO}_{2}$ & $\mathrm{TV}(\mathrm{ml} / \mathrm{kg})$ & Pplat $\left(\mathrm{cmH}_{2} \mathrm{O}\right)$ & $\mathrm{DP}\left(\mathrm{cmH}_{2} \mathrm{O}\right)$ & PEEP $\left(\mathrm{cmH}_{2} \mathrm{O}\right)$ & $\mathrm{pCO}_{2}$ & $\mathrm{FiO}_{2}$ \\
\hline 1 & 6 & 32 & 24 & 8 & 75 & 0.8 & 4.5 & 30 & 16 & 14 & 63 & 0.6 \\
\hline 2 & 6.4 & 27 & 16 & 6 & 71 & 1 & 4.5 & 23 & 10 & 10 & 59 & 0.75 \\
\hline 3 & 7.2 & 28 & 20 & 8 & 81 & 1 & 5 & 28 & 18 & 10 & 67 & 0.85 \\
\hline 4 & 7.8 & 31 & 18 & 12 & 65 & 1 & 4.6 & 28 & 13 & 14 & 57 & 0.9 \\
\hline 5 & 5.6 & 28 & 16 & 12 & 84 & 1 & 5 & 28 & 10 & 18 & 51 & 0.7 \\
\hline 6 & 6.7 & 28 & 11 & 14 & 66 & 0.9 & 6.5 & 25 & 9 & 16 & 51 & 0.7 \\
\hline 7 & 5.1 & 29 & 17 & 12 & 87 & 1 & 4 & 28 & 12 & 16 & 64 & 0.65 \\
\hline 8 & 6 & 30 & 18 & 8- & 77 & 80 & 4.2 & 26 & 14 & 12 & 62 & 0.75 \\
\hline
\end{tabular}

$\mathrm{N}=$ Number of cases, $\mathrm{TV}=$ tidal volume, $\mathrm{DP}=$ driving pressure

Regarding the outcome data on the $\mathrm{ECCO}_{2} \mathrm{R}$ device, the mean duration of therapy was 5.25 days, with a mean blood flow of $400 \mathrm{ml} / \mathrm{min}$ and air flow of $12 \mathrm{lpm}$. Fifty percentage of the patients survived, with an ICU discharge of 25 days (average value) after disconnection from the $\mathrm{ECCO}_{2} \mathrm{R}$. Case number 8 died within a day after removal of the $\mathrm{CO}_{2}$ extractor.

These cases, as in previous studies, show us the possible usefulness of applying $\mathrm{ECCO}_{2} \mathrm{R}$ based on individual clinical and physiological criteria [4], without development of serious complications, although other known published series report relevant complications [5].

$\mathrm{ECCO}_{2} \mathrm{R}$ system could be applied as a tool to optimise the degree of lung protection, essential in patients with severe ARDS. In our experience, $\mathrm{ECCO}_{2} \mathrm{R}$ is a simple and feasible therapeutic option for patients with severe respiratory diseases in whom conventional treatment has been maximised. Further studies are needed to strengthen the scientific evidence in this context [6].
Acknowledgements

We would like to thank all clinical members of the ICU team at H.U del Henares, who actively helped gather the data for the present article.

\section{Authors' contributions}

RML did investigation, writing original draft; BLV was involved in writing reviewing and editing. FG performed methodology, project administration, supervision and validation. All authors read and approved the final manuscript.

\section{Funding}

No financial support was required for the study. Financial support will be available in case of publication (throughFundación para la Investigación e Innovación Biomédicaof HospitalUniversitario Infanta Sofia and Hospital Universitario del Henares; Director: Marta Neira Álvarez).

\section{Availability of data and materials}

All data generated or analysed during this study are included in this published article.

\section{Declarations}

Ethical approval and consent to participate

Informed consent from patients or family member for the inclusion of medical data in our prospective ICU Registry was obtained. This study was conducted in accordance with the amended Declaration of Helsinki. Local institutional 
review boards and independent ethics committees (Healthcare Ethics Committee of the Francisco de Vitoria University) approved the protocol, and written informed consent was obtained from all patients.

\section{Consent for publication}

Consent for publication was forwarded by next of akin / family member through informed consent.

\section{Competing interests}

Authors declare no potential financial or ethical conflicts of interest.

\section{Author details}

'Intensive Care Unit. Hospital Universitario del Henares, Coslada-Madrid, Spain

${ }^{2}$ Grupo de Investigación en Patología Crítica, Facultad de Ciencias de La Salud, Universidad Francisco de Vitoria, Pozuelo de Alarcón, Madrid, Spain. ${ }^{3}$ Intensive Care Unit Head of Department, Hospital Universitario del Henares, Coslada, Madrid, Spain.

Received: 18 June 2021 Accepted: 29 September 2021

Published online: 18 October 2021

\section{References}

1. Combes A, Auzinger G, Capellier G, et al. ECCO2R therapy in the ICU: consensus of a European round table meeting. Crit Care. 2020;24:490. https:// doi.org/10.1186/s13054-020-03210-z.
2. Combes A, Schmidt M, Hodgson CL, et al. Extracorporeal life support for adults with acute respiratory distress syndrome. Intensive Care Med. 2020;46:2464-76. https://doi.org/10.1007/s00134-020-06290-1.

3. https:www.care-statement.org

4. Romay E, Ferre R. Eliminación extracorpórea de CO2: fundamentos fisiológicos y técnicos y principales indicaciones. Medicina Intensiva. 2016;40(1):33-8. https://doi.org/10.1016/j.medin.2015.06.001.

5. Combes A, Fanelli V, Pham T, et al. Feasibility and safety of extracorporeal $\mathrm{CO} 2$ removal to enhance protective ventilation in acute respiratory distress syndrome: the SUPERNOVA study. Intensive Care Med. 2019;45:592600. https://doi.org/10.1007/s00134-019-05567-4.

6. Kearsley R, Daly Guris R, Miles LF, Shelton CL. Case reports in the COVID-19 pandemic: first responders to an emergency in evidencebased medicine. Anaesthesia Rep. 2021;9(1):1-7. https://doi.org/10. 1002/anr3.12088.

\section{Publisher's Note}

Springer Nature remains neutral with regard to jurisdictional claims in published maps and institutional affiliations.
Ready to submit your research? Choose BMC and benefit from:

- fast, convenient online submission

- thorough peer review by experienced researchers in your field

- rapid publication on acceptance

- support for research data, including large and complex data types

- gold Open Access which fosters wider collaboration and increased citations

- maximum visibility for your research: over $100 \mathrm{M}$ website views per year

At BMC, research is always in progress.

Learn more biomedcentral.com/submissions 